\title{
Good hygiene practices in school canteens: evaluation between types of schools and administration as well as presence of technical professional
}

\author{
Boas práticas em cantinas no âmbito escolar: uma comparação \\ entre redes de ensino, tipos de administração e presença de \\ profissional técnico
}

\author{
Ana Claudia Pereira Wognski ${ }^{1}$, Caroline Choma ${ }^{1}$, Giovanni Ribeiro Gava ${ }^{1}$, \\ Bruna Gabriella Costa Schmitz Ferreira1', Laleska Pysklewitz Vieira1, \\ Elisângela Cristina de Oliveira', Vivian Cristina Santos ${ }^{1}$, Thais Regina Mezzomo², \\ Lize Stangarlin-Fiori ${ }^{3 *}$ (1)
}

${ }^{1}$ Universidade Positivo, Departamento de Nutrição, Curitiba/PR - Brasil.

${ }^{2}$ Centro Universitário Internacional (UNINTER), Departamento de Nutrição, Curitiba/PR - Brasil.

${ }^{3}$ Universidade Federal do Paraná (UFPR), Programa de Pós-graduação em Alimentação e Nutrição, Curitiba/PR Brasil.

*Corresponding Author: Lize Stangarlin-Fiori, Universidade Federal do Paraná (UFPR), Programa de Pósgraduação em Alimentação e Nutrição, Rua Prefeito Lothário Messner, 632, Jardim Botânico, CEP: 80210-170, Curitiba/PR - Brasil, e-mail: lizestangarlin@hotmail.com

Cite as: Wognski, A. C. P., Choma, C., Gava, G. R., Ferreira, B. G. C. S., Vieira, L. P., Oliveira, E. C., Santos, V. C., Mezzomo, T. R., \& Stangarlin-Fiori, L. (2021). Good hygiene practices in school canteens: evaluation between types of schools and administration as well as presence of technical professional. Brazilian Journal of Food Technology, 24, e2019257. https://doi.org/10.1590/1981-6723.25719

\begin{abstract}
The aim of the study was to evaluate the school canteens located within different types of schools, together with their types of administration and the presence of a technical professional regarding Good Hygiene Practices (GHPs). The observational study was conducted in 111 school canteens, 35 from private and 76 public schools in Curitiba, Brazil. A checklist based on national and international legislation on good hygiene practices -GHP was elaborated and applied during the work routine. With the list, the information was gathered about the type of administration and the presence of a technical professional (nutritionist) in these canteens. Most school canteens were classified as Regular, comprising between $50 \%$ and $69 \%$ of adequate assessment in relation to GHPs. The most unsatisfactory criteria were related to food temperature control, training of food handlers and Manual of GHPs and Standard Operating Procedures (SOP). Private school canteens were better classified than public school canteens in most of the categories evaluated $(p<0.05)$. In addition, the school canteens that have been outsourced and have also had a person technically responsible (nutritionist) $(p<0.01)$ presented the best results. This shows the need for the public school canteens with self-management systems and no technical professional to re-evaluate the sanitary criteria and to implement new strategies, as well as improving procedures for food temperature control, training of food handlers and elaboration of Manual of GHPs and SOP. Improvement with respect to these procedures will
\end{abstract}


assist in better control of food safety and prevent diseases in the student population, contributing to health promotion in the school environment.

Keywords: School feeding; Nutritionists; Self-management; Outsourced services; Food hygiene; Students.

\section{Resumo}

O objetivo do estudo foi avaliar as cantinas localizadas em diferentes tipos de escolas, de diferentes redes de ensino, tipos de administração e com a presença de profissional técnico em relação às boas práticas de higiene. $\mathrm{O}$ estudo observacional foi realizado em 111 cantinas, 35 de escolas particulares e 76 públicas de Curitiba/PR, Brasil. Uma lista de verificação, baseada na legislação nacional e internacional de boas práticas de higiene, foi elaborada e aplicada durante a rotina de trabalho. Juntamente com a lista, foram levantadas informações sobre o tipo de administração e a presença de um profissional técnico (nutricionista) nas cantinas. A maioria das cantinas escolares foi classificada como Regular, com 50\% e 69\% de adequação em relação às boas práticas de higiene. Os critérios mais insatisfatórios foram: controle da temperatura dos alimentos, treinamento de manipuladores de alimentos e Manual de Boas Práticas de Higiene e Procedimentos Operacionais Padrão. As cantinas de escolas particulares foram melhores que as de escolas públicas na maioria das categorias avaliadas $(p<0,05)$. Além disso, as cantinas terceirizadas e com responsável técnico (nutricionista) $(p<0,01)$ obtiveram os melhores resultados. Isso mostra a necessidade de as cantinas de escolas públicas com sistemas de autogestão e sem profissional técnico reavaliarem os critérios sanitários e implementar novas estratégias, para melhorar os procedimentos de controle da temperatura dos alimentos, treinamento para manipuladores de alimentos e elaboração do Manual de Boas Práticas de Higiene e dos Procedimentos Operacionais Padrão. A melhoria desses procedimentos ajudará no melhor controle da segurança dos alimentos e na prevenção de doenças na população estudantil, contribuindo para a promoção da saúde no ambiente escolar.

Palavras-chave: Alimentação escolar; Nutricionistas; Autogestão; Serviços terceirizados; Higiene dos alimentos; Estudantes.

\section{Introduction}

In Brazil, the food served in the school may occur in different places, and one of them being school canteens. Food and beverages are sold at this location (Gabriel et al., 2010). Its existence in the school is optional and the decision of the convenience and opportunity of installing the school canteen is up to the School Board, advised by the School Council (São Paulo, 2005).

The school canteen can serve as an important setting for nutrition and health promotion (Rathi et al., 2018; Wognski et al., 2019). Foods supplied by school canteens play a key role in food and nutritional security, and also highlight the Human Right to Adequate Food (HRAF) (Wognski et al., 2019). Given this, priority should be given to these places, not just concerning healthy foods, low in fat, sugar and sodium (Brasil, 2006), but also their health criteria for minimizing the risks of Foodborne Diseases (FBD), and ensuring the health and safety of students (Soares et al., 2018).

Among the places with the highest occurrence of FBD is the school environment. A study carried out in 2016 in the Ashanti region of Ghana, showed that $52 \%$ of the 180 students assessed, who ate more of their meals at school time, had FBD between 3 and 12 times per academic year (Ababio et al., 2016b). In Germany, one of the largest bouts of gastroenteritis in 2012 came from contaminated food in schools, compromising the health of 11,200 students (Aisha et al., 2016). In Brazil, this scenario is no different because, according to the Ministry of Health's Health Surveillance Secretariat, of the 12,503 FBD outbreaks that occurred between 2000 and 2017, 8.6\% occurred in the school environment (Brasil, 2018). Although there is no specific data regarding the outbreaks of FBD with specific reference to school canteens in Brazil, these locations represent a potential risk. 
Considering the need to improve actions for sanitary control of food in the school environment, the implementation of a Good Hygiene Practices (GHPs) program has been recommended (Lima et al., 2019; Serafim et al., 2018; Stangarlin-Fiori et al., 2016). The GHPs are considered a preventive program that establishes the minimum health requirements for the food preparation stages, aiming to increase food safety and the health of individuals (Lima et al., 2019; Serafim et al., 2018). The GHPs requirements required for Food Services in Brazil, such as canteens, are established by the National Health Surveillance Agency (in Portuguese Agência Nacional de Vigilância Sanitária (Anvisa)), through the Resolution of the Collegiate Board (in Portuguese Resolução de Diretoria Colegiada (RCB)) number 216 (Brasil, 2004).

In addition to GHPs, the World Health Organization (WHO) published in 2006 a "Five Keys to Safer Food" manual, which sets out the criteria for the highest risk areas in food handling as following: maintenance of cleanliness; separation of raw foods from cooked foods; sufficient food cooking time; maintenance of food at safe temperatures; and use safe water and raw materials (World Health Organization, 2006). These criteria, although not specific to food handling in school canteens, serve as a basis for the procedures to be prioritized during the food preparation stages.

Although there are studies that have already evaluated GHPs in the school environment, these studies have referred to school kitchens and not to school canteens (Ababio et al., 2016a, 2016b; Soares et al., 2018). In addition, few studies have evaluated the health criteria of canteens from the perspective of different types of schools, types of administration and the presence or absence of a technical professional (nutritionist), which makes the study necessary for the knowledge of school reality. Thus, the objective of the study was to compare the school canteens in different types of schools, as well as their type of administration and the presence or not of technical professionals within the context of GHPs.

\section{Material and methods}

\subsection{Type of study and sample design}

The observational, descriptive and cross-sectional study was conducted in canteens of public and private schools in the city of Curitiba, in the state of Paraná (PR), Brazil, from March 2016 to November 2017. The study was approved by the Research Ethics Committee of the Positivo University, registered under number 061073/2016.

To define the sample, a survey was carried out consisting of the number of elementary and secondary schools in the state and private schools in the city of Curitiba, registered with the Paraná Department of Education, resulting in 356 schools (Paraná, 2016), of which 141 presented school canteens. Based on this value, a prevalence of $50 \%$ was used, with a margin of error of 5 percentage points and a confidence interval of $95 \%$. The study sample consisted of at least 104 school canteens. All individuals from the school canteens were invited to participate in the research by telephone, and the study included those who were responsible for the canteen and showed agreement, by signing an Informed Consent Form, resulting in 111 canteens.

\subsection{Good hygiene practices assessment}

The definition of what sanitary criteria were developed to evaluate in the canteens was based on the parameters presented in the RCB n ${ }^{\circ}$ 216/2004 (Brasil, 2004), Resolution of the Paraná Department of Health $\mathrm{n}^{\circ}$ 0162/2005 (Paraná, 2005), a study by Stedefeldt et al. (2013), and the five keys to safer food established by the World Health Organization (2006).

Thirty-three items were selected, grouped by subject into eight categories, as follows: Physical structure (consisting of four items, regarding physical size $\left(\mathrm{m}^{2}\right)$, conservation and proper functioning of facilities, equipment, furniture and utensils; use of separate equipment, to avoid cross contamination; presence of a 
calibrated thermometer to food); Environmental hygiene (with five items regarding the proper hygiene conditions of the facilities, equipment, furniture and utensils; the correct frequency of hygiene; distinction between the material directly in contact with food from the equipment used for cooking and cleaning; and the origin and proper use of sanitizing products); Water supply (with three items related to the use of drinking water for food handling; structural conditions of water reservoir and sanitation); Food handlers (with six items regarding illnesses; proper hand hygiene; personal cleanliness; uniform consistent with the activity; and behaviors that prevent food contamination); Raw materials, ingredients and packaging (with six items related to the proper conditions of receiving the food; packing at temperature and proper identification and validity of the products); Handling steps (with 5 items related to the control of contact between ready-to-eat food and raw foods; exposure of perishable foods at room temperature; thawing and proper and controlled heat treatment; and quality control of oils and fats); Storage and commercialization of ready-to-eat food (with two items related to cold and hot packaging under adequate conditions and time; and adoption of commercialization procedures that minimize food contamination); Responsibility and documentation (with two items related to the implementation of the Manual of GHPs and Standard Operating Procedures (SOP); and presence of trained food handlers).

The list was applied during the work routine of the canteens, in the morning and afternoon shift, and conducted by study researchers who are food professionals and did not work in canteens, but underwent food safety training.

In completing the list, the items were evaluated as: adequate (AD) when the location met the required requirement, inappropriate (IN) when the requirement was not met, and not applicable (NA) when the requirement was not carried out in the school canteen under study. Afterwards, the percentage of general adequacy and adequacy by category was calculated, and the school canteens were classified as: Excellent when they presented 91 to $100 \%$ of adequacy; Good - when they presented 70 to $90 \%$ of adequacy; Regular - when they presented 50 to $69 \%$ of adequacy; Bad - when they presented 20 to $49 \%$ of adequacy; and Very Bad - when they presented 0 to $19 \%$ of adequacy (Stangarlin et al., 2013). Information was also collected on the type of canteen administration (self-management or outsourcing system), the presence and frequency of visits of a technical professional (nutritionist) to the site, and about the types of food that were marketed in canteens.

To evaluate the results obtained, the Statistical Analysis System (SAS), version 9.2 was used. Data were described using simple descriptive statistics (frequencies and percentages). To evaluate the association between the variables, the Analysis of Variance (ANOVA) was performed. A statistically significant difference was considered when $p<0.05$.

\section{Results and discussion}

Evaluation was carried out with 111 school canteens, 35 in private and 76 in public schools (Table 1). The main foods sold in the canteens were baked snacks (sfihas, croissant, puff pastry, calzone, hamburger, mini hot dog and pizza), processed snacks, chocolate, candies, stuffed cookies, natural sandwich, cheese buns, artificial juices, cassava starch crackers, fruit popsicle, mate tea (yerba mate), coconut water, among others. These foods were served warm or cold and the majority was purchased ready-to-eat or pre-cooked foods (cleaned and cooked), being only heated or finished in the school canteens.

Most of the school canteens were located in institutions of the state public school system (68.40\%), and were administered under self-management $(72.97 \%)$. In addition, there was a low percentage of technical professionals $(26.13 \%)$ in these schools. The presence of nutritionists was reported only in school canteens of private institutions (Table 1), and most nutritionists visited the facilities from 1 to 2 times a week, full time. 
Table 1. Administrative profile of commercial canteens located within schools. Curitiba, Paraná, Brazil, from 2016 to 2017.

\begin{tabular}{|c|c|c|c|c|c|c|c|c|c|c|}
\hline \multirow{3}{*}{ School } & & & \multicolumn{4}{|c|}{ Canteen Management Type } & \multicolumn{4}{|c|}{ Technical professional } \\
\hline & \multicolumn{2}{|c|}{ General } & \multicolumn{2}{|c|}{ Self-management } & \multicolumn{2}{|c|}{ Outsourced } & \multicolumn{2}{|c|}{ Presented } & \multicolumn{2}{|c|}{ Not presented } \\
\hline & $\mathbf{n}$ & $\%$ & $\mathbf{n}$ & $\%$ & $\mathbf{n}$ & $\%$ & $\mathbf{n}$ & $\%$ & $\mathbf{n}$ & $\%$ \\
\hline Private & 35 & 31.53 & 5 & 14.28 & 30 & 85.72 & 29 & 82.86 & 6 & 17.14 \\
\hline Public (State) & 76 & 68.40 & 76 & 100 & 0 & 0 & 0 & 0 & 76 & 100 \\
\hline Total & 111 & 100 & 81 & 72.97 & 30 & 27.03 & 29 & 26.13 & 82 & 73.87 \\
\hline
\end{tabular}

Caption: $\mathrm{n}$ : number of school canteens evaluated. \%: percentage calculated considering the total of school canteens.

The higher frequency of canteens located in public schools reported in this study disagrees with the results of the studies of other researchers in Brazil (Gabriel et al., 2010; Instituto Brasileiro de Geografia e Estatística, 2013; Giacomelli et al., 2017), where there was a higher prevalence of canteens located in private institutions. This result may be related to the significant number of public schools participating in this study, resulting in a larger number of their canteens reported for this type of school.

The installation of canteens in schools is widespread, especially in public schools. This shows that students from public schools in the municipality, in addition to having permanent access to food through the National School Meal Program (Programa Nacional de Alimentação Escolar (PNAE)), considered the oldest program of the Brazilian government in the area of school feeding (Brasil, 2015), and could also seek alternative pathways for food consumption by purchasing snacks from canteens. Given this, it is necessary to control and improve the sanitary criteria in the stages of food handling in these places, in order to ensure the safety of the snacks sold.

Moreover, the canteen as a direct responsibility of the school itself, with a self-management system, is not a common practice observed in other Brazilian schools (Gabriel et al., 2010; Giacomelli et al., 2017). This is owing to the responsibility for managing the school canteen is an extra burden for the school administration or for representatives of the parent, teacher and staff association, in which it may be a work overload for these people who are responsible for other activities.

In the evaluation of GHPs, the school canteens had an overall average of $55.52 \%$ of adequacy, being classified as Regular. Among the categories evaluated, $12.5 \%$ of the canteens were classified as Good, $62.5 \%$ as Regular and $25 \%$ as Bad (Table 2). Other studies have also identified a low percentage of adequacy of sanitary criteria in school canteens (Porto et al., 2015; Verdum et al., 2017), and reveal the weakness that still exists in this school feeding segment in relation to food safety.

In this study, it was observed that some pre-cooked foods are distributed in the canteens, i.e., being already cleaned and cooked, and, therefore, do not undergo any process locally that could eliminate any potential microbial load. Therefore, if they could be recontaminated due to negligence about using good practice criteria, the risk of consuming these foods increases, which can directly affect student's health.

According to Dudeja et al. (2017), the greater the number of inadequate sanitary conditions in these establishments is, the greater the risk of contamination will be. Consumption by children of contaminated foods may cause gastrointestinal disorders such as nausea, vomiting and diarrhea and may cause the death of vulnerable individuals (Brasil, 2018).

Therefore, the implementation of GHPs is essential to promote better administrative control and greater safety in the food preparation in school canteens. The GHPs involve a systematic approach to the control of food contaminants and provide significant changes in the work routine of companies through suggestions for adequacy and standardization of procedures (Nik Husain et al., 2016). The implementation of the GHPs program also promotes improvements in the behavior of food managers and food handlers in relation to food safety (Lima et al., 2019; Serafim et al., 2018). However, the application of GHPs in school canteens reflects 
the involvement, investment, knowledge and constant evaluation of canteen administrators, school heads and public legislation. Therefore, joint intervention at all three levels is needed as a strategy for improving health.

A study by Stangarlin et al. (2013), carried out in hospitals, which present a higher risk due to the type of customers, observed a positive correlation between more frequent visits by official inspectors and the adherence to GHPs. The same authors highlighted that the constant inspections and the requirement of sanitary criteria by the official legislators make these items a priority and indispensable. It is noteworthy that the city of Curitiba published in 2018 a new Resolution (Curitiba, 2018), which classifies food establishments as high and low risk, and establishes new deadlines for inspection visits to these establishments.

This Resolution does not address inspection for preventive measures. Most food establishments, such as the school canteens, are exempt from the prior inspection process for issuance of a health license, which is valid for five years. Therefore, the application of GHPs to this segment may be compromised from now on, seeing that these measures have been adopted in the municipality and will require greater efforts by schools and canteen managers to ensure the safety of food sold in these establishments.

In the general analysis, considering the public and private canteens (Table 2), it was found that Environmental Hygiene was the category with the highest adequacy percentage $(80.40 \%)$, being classified as Good, while the Storage and ready-to-eat food (22.14\%) and Responsibility and documentation (27.85\%) were the least adequate items, both classified as Bad (Table 2). In addition, the categories of Storage and marketing of ready-to-eat food and Responsibility and documentation did not present any adequate items in public school canteens, both being classified as Very Bad.

Table 2. Evaluation of Good Hygiene Practices (GHPs) in commercial canteens located in different types school. Curitiba, Paraná, Brazil, from 2016 to 2017.

\begin{tabular}{|c|c|c|c|c|c|c|c|}
\hline \multirow{2}{*}{ Categories } & \multicolumn{2}{|c|}{$\begin{array}{l}\text { Total canteens } \\
\quad(n=111)\end{array}$} & \multicolumn{2}{|c|}{$\begin{array}{l}\text { Canteens in private } \\
\operatorname{school}(n=35)\end{array}$} & \multicolumn{2}{|c|}{$\begin{array}{l}\text { Canteens in public } \\
\text { school }(n=76)\end{array}$} & \multirow{2}{*}{$\mathbf{p}^{*}$} \\
\hline & $\%$ AD & CLAS & $\%$ AD & CLAS & $\%$ AD & CLAS & \\
\hline Physical structure & 50.26 & Regular & 63.57 & Regular & 36.95 & $\mathrm{Bad}$ & $<0.01$ \\
\hline Environmental hygiene & 80.40 & Good & 90.28 & Good & 70.52 & Good & $<0.01$ \\
\hline Water supply & 66.76 & Regular & 58.09 & Regular & 75.43 & Good & $<0.01$ \\
\hline Food handlers & 52.44 & Regular & 66.47 & Regular & 38.42 & $\mathrm{Bad}$ & $<0.01$ \\
\hline $\begin{array}{l}\text { Raw materials, ingredients and } \\
\text { packaging }\end{array}$ & 58.42 & Regular & 69.04 & Regular & 47.80 & $\mathrm{Bad}$ & $<0.01$ \\
\hline Handling Steps & 54. 22 & Regular & 59.42 & Regular & 49.03 & Bad & 0.04 \\
\hline $\begin{array}{l}\text { Storage and marketing of ready-to- } \\
\text { eat food }\end{array}$ & 22.14 & $\mathrm{Bad}$ & 44.28 & $\mathrm{Bad}$ & 0.00 & $\begin{array}{l}\text { Very } \\
\text { Bad }\end{array}$ & $<0.01$ \\
\hline Responsibility and documentation & 27.85 & $\mathrm{Bad}$ & 55.71 & Regular & 0.00 & $\begin{array}{l}\text { Very } \\
\text { Bad }\end{array}$ & $<0.01$ \\
\hline Overall Average & 55.52 & Regular & 66.23 & Regular & 44.82 & $\mathrm{Bad}$ & $<0.01$ \\
\hline
\end{tabular}

Caption:\% AD: percentage of adequacy considering the total of canteens evaluated in each group. CLAS: canteen rating: Excellent - when it raised the percentage from $91 \%$ to $100 \%$ for adequate assessment; Good - from $70 \%$ to $90 \%$ for adequate assessment; Regular - from $50 \%$ to $69 \%$ for adequate assessment; Bad - from $20 \%$ to $49 \%$ for adequate assessment; and Very Bad - from $0 \%$ to $19 \%$ for adequate assessment. *Significant difference at $5 \%$ probability by analysis of variance (ANOVA).

The main flaws observed in these categories were the absence of thermometers and thermostats to control the temperature of perishable foods; frequent exposure of pre-prepared and prepared foods to room temperature; lack of trained personnel and employee training records; and lack of a Manual of GHPs and SOP. 
These failures were evidenced in study conducted on school food services in Brazil (Cunha et al., 2018), and could demonstrate a lack of knowledge on the part of school canteen managers about basic health criteria which are essential criteria for food handling (Barjaktarović-Labović et al., 2018; Cunha et al., 2018).

Food temperature control is considered one of the most important factors in preventing microbial growth and FBD outbreaks (Barjaktarović-Labović et al., 2018). Temperatures between $4{ }^{\circ} \mathrm{C}$ to $60{ }^{\circ} \mathrm{C}\left(40{ }^{\circ} \mathrm{F}\right.$ to $140^{\circ} \mathrm{F}$ ) are considered danger zones and the longer the exposure time of foods to this temperature range is, the greater the possibility of multiplication of potentially harmful microorganisms will be, which may compromise the quality of the food sold (Wiethölter \& Fassina, 2017). Regarding this subject and also taking into account that many foods in the canteens require refrigeration or heating for consumption, temperature control of these foods is crucial to minimize the risks of contamination.

The lack of adequacy quality control in the category of responsibility and documentation may undermine the conduct adopted in the school canteens regarding the implementation of GHPs, as documentation assists in the standardization of work processes, performance evaluation, employee orientation for the correct execution of tasks and generate a history of the procedures performed (Serafim et al., 2018). Thus, the documents, monitoring and records of hygiene practices assist in preventing inadequacies and, consequently, illnesses related to processes in food handling (Boff \& Strasburg, 2018).

In addition, the lack of trained employees can also negatively impact food quality, as there is a positive correlation between what food handlers know about the business and their attitudes towards GHPs (Serafim et al., 2018). Training is important to increase food safety, seeing that it is essential for information dissemination and for stimulating the participation and understanding of transmitted concepts (Serafim et al., 2018).

When the canteens of different schools were evaluated in relation to GHPs (Table 2), it could be found that those located in a private school, compared to the public, were more adequate in most categories evaluated $(p<0.05)$. This result is mainly due to the better financial and physical conditions of canteens located in private schools, when compared to public ones (Rudakoff et al., 2018).

However, an inadequate physical structure allows the use of improvised and inadequate equipment that may directly interfere with production flow and favor food contamination (Cunha et al., 2019; Nik Husain et al., 2016; Rudakoff et al., 2018). In addition, the scarcity of financial resources in some institutions makes it difficult to invest in the purchase of new equipment and the hiring of external resources that may assist in the suggestions for improvements, or in hiring outsourced companies for operational services, in the description of documents, and in the qualifications and motivation of employees. Moreover, this scarcity of financial resources compromises the physical maintenance and renovation of the establishment (Serafim et al., 2018). Both points are essential to ensure the effectiveness of the GHPs program.

In this study, Water supply was the only category that presented better results in the canteens of public institutions than in private ones. This fact is related mainly to the irregularities regarding the frequency of sanitation of the water reservoir and the lack of evidence regarding the procedure. This result demonstrates that the administrators of educational establishments are not committed to the current sanitary legislation (Brasil, 2004), as these requirements are their responsibility. Even though it is the responsibility of school to maintain the water reservoirs clean, the canteens located in these places must require the proper performance and proof of this procedure. This is because water is an important determinant of GHPs in school canteens, being used, among other purposes, for consumption, sanitation, food preparation and personal and environmental hygiene (Lima et al., 2019), and may more involved in FBD outbreaks.

It was found that the outsourced canteens $(p<0.01)$ and those with a technical person responsible (nutritionist) $(p<0.01)$ presented better results in relation to GHPs $(p<0.05)$ (Table 3$)$. 
Table 3. Evaluation of Good Hygiene Practices (GHPs) of commercial canteens located within the school with different types of administration and presence or absence of technical professional (nutritionist). Curitiba, Paraná, Brazil, from 2016 to 2017.

\begin{tabular}{|c|c|c|c|c|c|c|c|c|c|c|}
\hline \multirow{2}{*}{$\begin{array}{l}\text { Categories of } \\
\text { canteens }\end{array}$} & \multicolumn{2}{|c|}{$\begin{array}{c}\text { Outsourced } \\
(n=30)\end{array}$} & \multicolumn{2}{|c|}{$\begin{array}{l}\text { Self-managed } \\
\quad(n=81)\end{array}$} & \multirow[t]{2}{*}{$\mathbf{p}^{*}$} & \multicolumn{2}{|c|}{$\begin{array}{c}\text { Presence of } \\
\text { professional }(n=29)\end{array}$} & \multicolumn{2}{|c|}{$\begin{array}{c}\text { No professional } \\
(\mathbf{n}=82)\end{array}$} & \multirow[t]{2}{*}{$\mathbf{p}^{*}$} \\
\hline & $\% A D$ & CLAS & $\% A D$ & CLAS & & $\% A D$ & CLAS & $\% A D$ & CLAS & \\
\hline $\begin{array}{l}\text { Physical } \\
\text { structure }\end{array}$ & 65.32 & Regular & 37.60 & $\mathrm{Bad}$ & $<0.01$ & 67.24 & Regular & 37.60 & $\mathrm{Bad}$ & $<0.01$ \\
\hline $\begin{array}{c}\text { Environmental } \\
\text { hygiene }\end{array}$ & 90.96 & Good & 71.25 & Good & $<0.01$ & 92.41 & Excellent & 71.21 & Good & $<0.01$ \\
\hline Water supply & 59.13 & Regular & 74.16 & Good & $<0.01$ & 60.91 & Regular & 73.17 & Good & 0.03 \\
\hline Food handlers & 68.06 & Regular & 39.20 & $\mathrm{Bad}$ & $<0.01$ & 73.90 & Good & 37.84 & Bad & $<0.01$ \\
\hline $\begin{array}{l}\text { Raw materials, } \\
\text { ingredients and } \\
\text { packaging }\end{array}$ & 70.43 & Good & 48.33 & $\mathrm{Bad}$ & $<0.01$ & 71.26 & Good & 48.57 & $\mathrm{Bad}$ & $<0.01$ \\
\hline Handling Steps & 61.93 & Regular & 48.58 & $\mathrm{Bad}$ & $<0.01$ & 62.75 & Regular & 48.61 & Bad & $<0.01$ \\
\hline $\begin{array}{l}\text { Storage and } \\
\text { marketing of } \\
\text { ready food }\end{array}$ & 46.77 & $\mathrm{Bad}$ & 1.25 & $\begin{array}{l}\text { Very } \\
\text { Bad }\end{array}$ & $<0.01$ & 50.00 & Regular & 1.21 & $\begin{array}{l}\text { Very } \\
\text { Bad }\end{array}$ & $<0.01$ \\
\hline $\begin{array}{l}\text { Responsibility } \\
\text { and } \\
\text { documentation }\end{array}$ & 59.67 & Regular & 1.25 & $\begin{array}{l}\text { Very } \\
\text { Bad }\end{array}$ & $<0.01$ & 63.79 & Regular & 1.21 & $\begin{array}{l}\text { Very } \\
\text { Bad }\end{array}$ & $<0.01$ \\
\hline Overall Average & 67.93 & Regular & 45.23 & Bad & $<0.01$ & 70.32 & Good & 44.94 & Bad & $<0.01$ \\
\hline
\end{tabular}

Caption: \% AD: percentage of adequate assessment considering the total of canteens evaluated in each group. CLAS: canteen rating: Excellent - when it raised the percentage from $91 \%$ to $100 \%$ for adequate assessment; Good - from $70 \%$ to $90 \%$ for adequate assessment; Regular - from $50 \%$ to $69 \%$ for adequate assessment; Bad - from $20 \%$ to $49 \%$ for adequate assessment; and Very Bad - from $0 \%$ to $19 \%$ for adequate assessment. *Significant difference at $5 \%$ probability by Analysis of Variance (ANOVA).

The outsourcing of school food services is associated with a system where the execution of activities related to food is delegated to a specialized company responsible for the whole process. In these cases, it is up to the educational institutions, as a contractor, to monitor and control these activities. Thus, outsourced canteens generally meet the sanitary criteria more adequately (Rudakoff et al., 2018), as they are required by contract to meet these requirements.

In addition, outsourced canteen providers are, in most cases, linked to larger collective meal companies with contracts in other places, and that are already accustomed to the implementation of sanitary procedures and quality audits, which corroborates the adequacy of GHPs, as evidenced in this study.

In this study, although the Nutritionist was not present daily monitoring the work routine in the canteens, it was observed that this professional plays an important role in the canteens, contributing to the adequacy of hygiene practices. The importance of the responsible technician (nutritionist) in improving the sanitary criteria in food services has also been shown in other studies (Cunha et al., 2018; Serafim et al., 2018; Boff \& Strasburg, 2018; Lima et al., 2019). This professional is able to unite knowledge about food safety with food service management, leading to better adherence to GHPs procedures (Cunha et al., 2018).

This professional can also assist in appointing external suppliers of products and services, clarifying doubts and motivating food owners and handlers (Lima et al., 2019; Stangarlin-Fiori et al., 2016). Given this, it is noted that school canteens must give a professional character to encompass significant role of the nutritionist as a food supervisor and health educator, in order to meet the legal requirements (Ruwer \& Mainbourg, 2015) and to ensure the implementation of safety strategies for food. This will improve work activities and the quality of the food provided at these establishments. 
The results of this research are relevant, however, it has as limitation associated with the fact that the research was conducted only in a Brazilian capital, and may not reflect the evaluation of GHPs of school canteens in other cities and regions of the country.

\section{Conclusion}

Most school canteens were classified as Regular, with a percentage of adequate assessment between $50 \%$ and $69 \%$ in relation to good hygienic practices - GHPs.

The canteens located in a private school, with self-management systems and visits from a technical professional (nutritionist) were the ones that had the best results in relation to GHPs. This result showed the need for the public school canteens with self-management systems and also for those schools without technical professional to re-evaluate the sanitary criteria and to implement new strategies to improve procedures for food temperature control, training of food handlers and elaboration of Manual of GHPs and Standard Operating Procedures.

Improvement of these procedures will assist in better control of food safety and prevent FBD in the student population, contributing to health promotion in the school environment.

\section{References}

Ababio, P. F., Taylor, K. D. A., Swainson, M., \& Daramola, B. A. (2016a). Effect of good hygiene practices intervention on food safety in senior secondary schools in Ghana. Food Control, 60, 18-24. http://dx.doi.org/10.1016/j.foodcont.2015.07.013

Ababio, P. F., Taylor, K. D. A., Swainson, M., \& Daramola, B. A. (2016b). Impact of food hazards in school meals on students' health, academic work and finance - Senior High School students' report from Ashanti Region of Ghana. Food Control, 62, 5662. http://dx.doi.org/10.1016/j.foodcont.2015.10.017

Aisha, A., Baboucarr, J., Fatima, A. D., Sharifa, A. M., \& Feryal, A. S. (2016). An overview of food safety knowledge and practices in selected schools in the city of Al Ain, United Arab Emirates. African Journal of Microbiological Research, 10(15), 511-520. http://dx.doi.org/10.5897/AJMR2016.7917

Barjaktarović-Labović, S., Mugoša, B., Andrejević, V., Banjari, I., Jovićević, L., Djurović, D., Martinović, A., \& Radojlović, J. (2018). Food hygiene awareness and practices before and after intervention in food services in Montenegro. Food Control, 85 , 466-471. http://dx.doi.org/10.1016/j.foodcont.2017.10.032

Boff, J. M., \& Strasburg, V. J. (2018). Avaliação da efetividade de boas práticas em serviços de alimentação coletiva em uma capital brasileira. Revista Saúde, 44(1), 1-9. http://dx.doi.org/10.5902/2236583425334

Brasil. Ministério da Saúde. Agência Nacional de Vigilância Sanitária - ANVISA. (2004, setembro 15). Aprova o Regulamento Técnico de Boas Práticas para Serviços de Alimentação (Resolução - RDC n²16, de 15 de setembro de 2004). Diário Oficial da República Federativa do Brasil, Brasília. Retrieved in 2018, January 13, from

http://portal.anvisa.gov.br/documents/33916/388704/RESOLU\%25C3\%2587\%25C3\%2583O-

RDC\%2BN\%2B216\%2BDE\%2B15\%2BDE\%2BSETEMBRO\%2BDE\%2B2004.pdf/23701496-925d-4d4d-99aa-9d479b316c4b

Brasil. Ministério da Educação. (2006, maio 8). Institui as diretrizes para a promoção da alimentação saudável nas escolas de educação infantil, fundamental e nível médio das redes públicas e privadas, em âmbito nacional (Portaria interministerial $n^{\circ}$ 1010, de 8 de maio de 2006). Diário Oficial da República Federativa do Brasil, Brasília. Retrieved in 2018, January 13, from http://bvsms.saude.gov.br/bvs/saudelegis/gm/2006/pri1010_08_05_2006.html

Brasil. Ministério da Educação. (2015). Cartilha Nacional da Alimentação Escolar. Retrieved in 2019, September 18, from https://www.educacao.sp.gov.br/a2sitebox/arquivos/documentos/960.pdf

Brasil, Ministério da Saúde. Coordenação Geral de Doenças Transmissíveis. (2018). Surtos de doenças transmitidas por alimentos no Brasil. Retrieved in 2018, January 13, from http://portalarquivos2.saude.gov.br/images/pdf/2018/janeiro/17/Apresentacao-Surtos-DTA-2018.pdf

Cunha, D. T., Amorim, A. L. B., Leite, F. H. M., Stedefeldt, E., Rosso, V. V., \& Bandoni, D. H. (2019). Dimensioning of the physical area and required number of food handlers for school food services. Revista de Nutrição, 32, 1-12. http://dx.doi.org/10.1590/1678-9865201932e180188

Cunha, D. T., Rosso, V. V., \& Stedefeldt, E. (2018). Food safety performance and risk of food services from different natures and the role of nutritionist as food safety leader. Ciência \& Saúde Coletiva, 23(12), 4033-4042. PMid:30539988. http://dx.doi.org/10.1590/1413-812320182312.21042016

Curitiba. Secretaria Municipal da Saúde. (2018, julho 23). Dispõe sobre processo de licenciamento sanitário inicial e de renovação para os estabelecimentos de interesse a saúde pela Vigilância Sanitária Municipal para instalação e funcionamento no Município de Curitiba e dá outras providências (Resolução - RDC n 2, de 23 de julho de 2018). Diário Oficial do Município, Curitiba. Retrieved in 2018, January 13, from https://www.legisweb.com.br/legislacao/?id=365452 
Dudeja, P., Singh, A., Sahni, N., Kaur, S., \& Goel, S. (2017). Effectiveness of an intervention package on knowledge, attitude, and practices of food handlers in a tertiary care hospital of north India: A before and after comparison study. Medical Journal, Armed Forces India, 73(1), 49-53. PMid:28123245. http://dx.doi.org/10.1016/j.mjafi.2016.10.002

Gabriel, C. G., Santos, M. V., Vasconcelos, F. A. G., Milanez, G. H. G., \& Hulse, S. B. (2010). School canteens of Florianópolis: existence and foods for sale after the institution of the law of regulation. Revista de Nutrição, 23(2), 191-199. http://dx.doi.org/10.1590/S1415-52732010000200002

Giacomelli, S. C., Londero, A. M., Benedetti, F. J., \& Saccol, A. L. F. (2017). Informal and formal food trade in the school environment in a city in the central region of Rio Grande do Sul, Brazil. Brazilian Journal of Food Technology, 20, e2016136. Retrieved in 2018, January 13, from http://www.scielo.br/pdf/bjft/v20/1981-6723-bjft-20-e2016136.pdf

Instituto Brasileiro de Geografia e Estatística - IBGE. (2013). Pesquisa Nacional de Saúde do Escolar 2012 (PENSE 2012). Retrieved in 2018, January 13, from https://biblioteca.ibge.gov.br/visualizacao/livros/liv64436.pdf

Lima, D. P., Medeiros, C. O., Dardin, F. D., \& Stangarlin-Fiori, L. (2019). Implementation of good hygiene practices in food trucks with and without the intervention of a food safety expert. Journal of Food Safety, 39(3), 1-7. http://dx.doi.org/10.1111/jfs.12637

Nik Husain, N. R., Wan Muda, W. M., Noor Jamil, N. I., Nik Hanafi, N. N., \& Abdul Rahman, R. (2016). Efeito do treinamento em segurança alimentar em conhecimentos e práticas dos manipuladores de alimentos. British Food Journal, 118(4), 795-808. http://dx.doi.org/10.1108/BFJ-08-2015-0294

Paraná. Secretaria de Estado de Saúde do Paraná. (2005, fevereiro 4). Aprovar a Norma Técnica, anexa, a qual estabelece exigências sanitárias para centros de educação infantil, independente do nome fantasia que utilizem (Resolução - RDC $n^{\circ} 162$, de 4 de fevereiro de 2005). Diário Oficial do Estado. Retrieved in 2018, January 13, from https://sogi8.sogi.com.br/Arquivo/Modulo113.MRID109/Registro12724/documento\%201.pdf

Paraná. Secretaria de Educação. (2016). Consultas escolas. Retrieved in 2018, January 13, from http://www4.pr.gov.br/escolas/listaescolas.jsp

Porto, E. B. S., Schmitz, B. A. S., Recine, E., \& Rodrigues, M. L. C. F. (2015). Sanitary conditions and associated factors of school canteens in the Federal District, Brazil. Vigilância Sanitária em Debate: Sociedade, Ciência \& Tecnologia, 3(4), 128-135. http://dx.doi.org/10.3395/2317-269x.00317

Rathi, N., Riddell, L., \& Worsley, A. (2018). The role of Indian school canteens in nutrition promotion. British Food Journal, 120(1), 196-209. http://dx.doi.org/10.1108/BFJ-05-2017-0275

Rudakoff, L. C. S., Mouchreck, A. N., Frota, M. T. B. A., \& Bastos, L. D. S. (2018). Quality and food safety in school feeding and nutrition units from public schools from São Luís, State of Maranhão. Vigilância Sanitária em Debate: Sociedade, Ciência \& Tecnologia, 6(3), 46-53. http://dx.doi.org/10.22239/2317-269x.01094

Ruwer, C. M., \& Mainbourg, E. M. T. (2015). Sanitary conditions of school canteens in the private schools network, before and after the licensing of health. Vigilância Sanitária em Debate: Sociedade, Ciência \& Tecnologia, 3(2), 85-93. http://dx.doi.org/10.3395/2317-269x.00479

São Paulo. Secretaria da Educação. (2005, março 23). Normas para funcionamento de cantinas escolares (Portaria Conjunta COGSP/CEI/DSE, de, 23 de março de 2005). Diário Oficial do Estado de São Paulo. Retrieved in 2018, January 13, from http://siau.edunet.sp.gov.br/ltemLise/arquivos/notas/portconj_cogsp_cei_dse(doe230305).htm

Serafim, A. L., Stangarlin-Fiori, L., \& Hecktheuer, L. H. R. (2018). Good handling practices in food and beverage areas of hotels: evaluation of improvements achieved versus financial investments. Journal of Food Safety, 38(6), 1-11. http://dx.doi.org/10.1111/jfs.12543

Soares, D. S. B., Henriques, P., Ferreira, D. M., Dias, P. C., Pereira, S., \& Barbosa, R. M. S. (2018). Boas práticas em unidades de alimentação e nutrição escolares de um município do estado do Rio de Janeiro - Brasil. Ciência \& Saúde Coletiva, 23(12), 4077-4083. PMid:30539992. http://dx.doi.org/10.1590/1413-812320182312.23992016

Stangarlin, L., Hecktheuer, L. H., Serafim, A. L., \& Medeiros, L. B. (2013). Evaluation of hygienic-sanitary conditions of hospital nutrition and dietary services from the perspectives of internal and external auditors. Food Science and Technology, 33(3), 521525. http://dx.doi.org/10.1590/S0101-20612013005000058

Stangarlin-Fiori, L., Medeiros, L. B., Serafim, A. L., Bertin, R. L., Medeiros, C. O., \& Hecktheuer, L. H. (2016). Good hygiene practices in hospital nutrition services: The view of internal and external auditors. Food Science and Technology, 36(3), 461467. http://dx.doi.org/10.1590/1678-457X.00315

Stedefeldt, E., Cunha, D. T., Junior, E. A. S., Silva, S. M., \& Oliveira, A. B. A. (2013). Instrument for assessment of best practices in school food and nutrition units: from design to validation. Ciência \& Saúde Coletiva, 18(4), 947-953.

PMid:23670370. http://dx.doi.org/10.1590/S1413-81232013000400006

Verdum, D. P., Da Silva, J. P., Capatti, F., Pereira, M. B. L. S., Kirsten, V. R., \& Brasil, C. C. B. (2017). Hygienic-sanitary conditions of state schools cafeterias in town of Palmeira das Missões, Rio Grande do Sul. Vigilância Sanitária em Debate: Sociedade, Ciência \& Tecnologia, 5(4), 1-6. http://dx.doi.org/10.22239/2317-269x.00960

Wiethölter, M. J., \& Fassina, P. (2017). Temperaturas de armazenamento e distribuição dos alimentos. Segurança Alimentar e Nutricional, 24(1), 17-25. http://dx.doi.org/10.20396/san.v24i1.8646468

Wognski, A. C. P., Ponchek, V. L., Schueda Dibas, E. E., Orso, M. R., Vieira, L. P., Ferreira, B. G. C. S., Mezzomo, T. R., \& Stangarlin-Fiori, L. (2019). Commercialization of food in school canteens. Brazilian Journal of Food Technology, 22, e2018198. http://dx.doi.org/10.1590/1981-6723.19818 
Good hygiene practices in school canteens: evaluation between types of schools and administration as well as presence of technical professional

Wognski, A. C. P. et al.

World Health Organization - WHO. (2006). Five keys to safer food manual. Genebra: WHO. Retrieved in 2018, January 13, from https://www.who.int/foodsafety/publications/consumer/manual_keys.pdf

Funding: None.

Received: Sept. 18, 2019; Accepted: Dec. 08, 2020 